\title{
感光色素の抗菌作用について（貣）
}

特に Styryl 系色素の系状菌に対する抗菌作用

関西医科大学微生物学教室

大沢 忍, 井上恵美子; 栗本栄子, 川原福江, 簡 雪桜, 小野あや

\section{Antibiotic Effects of Styryl Compounds on Tungi and Yeasts.}

Shinobu Osawa, Emiko Inoue, Eiko Kurimoto, Setsuo Kan and Aya Ono.

Department of Microbiology Kansai Medical School, Osaka.

A study is made antibiotic effects of 10 kind of photosensitive dyes having a styryl bond with halogen alkylate of chinolin and pyridine with following results:

1) T112 and T116 show antibiotic effects to Saccharomyces at $0.27 \mathrm{pmm}$.

2) T112 and T116 show antibiotic effects to Trychophyton below 1.0 pmm.

3) No significant growth inhibiting effects are found for Penicillium.

4) The drugs used show no satisfactory effects for preventing putrefaction of milk.

Styryl 系の感光色素の若干について一般細菌に 対する抗菌作用を前報で述べたが，ててでは引続 いて行つた同じ一列の感光色素の糸状菌その他に 関する作用について記す。

\section{供試材料並ひに英雅方法}

感光色素（前報所載）は何れも既述の如く $2 \%$ 重曹水に1: 10.000 1 : 20.000亿溶解し, 培地に は普通ブイョン, 寒天培地又はブドウ糖加 Sabouraudを用いた。

牛乳の酸敗阻止に関しては市販牛乳をそのまま 用い，これに色素液を加えた。
菌株は下記の何れも教室保存のものである，微 類と醅母を主とした。

Saccheromyces (パン醉母) 2 株

酒酵母

ビール醉母

Trychophyton (rubrum) \& T. interdigitalis Gibberelle furikuroi

Penicillium ristatum 233 \& B. 25

成

成績の概要を総括的に表示すればとの表の如く になる。

発育阻止の稀釈倍数を示す. 単位 $1: 10,000$, 十田屾微弱発育

\begin{tabular}{|c|c|c|c|c|c|c|c|c|c|c|}
\hline 使用菌株 & $\begin{array}{c}1 \\
\mathrm{~T}_{71}\end{array}$ & $\begin{array}{c}2 \\
T_{72}\end{array}$ & $\begin{array}{c}3 \\
T_{100}\end{array}$ & $\begin{array}{c}4 \\
T_{101}\end{array}$ & $\begin{array}{c}5 \\
T_{104}\end{array}$ & $\begin{array}{c}6 \\
T_{105}\end{array}$ & $\begin{array}{c}7 \\
T_{106}\end{array}$ & $\begin{array}{c}8 \\
T_{112} \\
\end{array}$ & $\begin{array}{c}9 \\
T_{118} \\
\end{array}$ & $\begin{array}{c}10 \\
T_{110}\end{array}$ \\
\hline $\begin{array}{c}\text { Saccharomyces } \\
\text { (Oriental) }\end{array}$ & 5 & $9+$ & 5 & $9+$ & $120+$ & $9 \pm$ & $370+$ & 35 & 18 & 370 \\
\hline $\begin{array}{c}\prime \prime \\
\text { (Australia) }\end{array}$ & 5 & $9+$ & 5 & $9+$ & $120+$ & $9_{ \pm}$ & $370+$ & 35 & 18 & 370 \\
\hline (Sake) & 5 & 9 & 5 & $9+$ & $\mathbf{9}_{ \pm}$ & $9+$ & $370+$ & 35 & 18 & 370 \\
\hline (Beer) & & & & & & & & & & \\
\hline
\end{tabular}




\begin{tabular}{c|c|c|c|c|c|c|c|c|c|c}
\hline $\begin{array}{c}\text { Trychophyton } \\
\text { rubrum }\end{array}$ & $9 ?$ & $9 ?$ & $>9$ & $>7$ & 370 & 35 & $35 \sim 370+$ & $170+$ & $140+$ & 120 \\
\hline $\begin{array}{c}\text { I" } \\
\text { interdigitale }\end{array}$ & $9 ?$ & 9 & $>9$ & 9 & $9 \sim 18$ & 70 & $35+$ & $170+$ & $35 ?$ & 120 \\
\hline $\begin{array}{c}\text { Gibberella } \\
\text { fujikuroi }\end{array}$ & $>5$ & $>5$ & $>9$ & $>9$ & $>9$ & $>9$ & $>35$ & $>35$ & $>35$ & $>35$ \\
\hline $\begin{array}{c}\text { Penicillium } \\
\text { notatum 233 }\end{array}$ & $>5$ & $>5$ & $>9$ & $>9$ & $>9$ & $>9$ & $>35$ & $>35$ & $>18$ & $>35$ \\
\hline B 25 & $>5$ & $>5$ & $>9$ & $>9$ & $>9$ & $>9$ & $>35$ & $>35$ & $>18$ & $>35$ \\
\hline
\end{tabular}

Saccharomyces 亿対する作用は比較的明瞭に判 定出来るが Tryptophyton P Penicillium に対 する作用は実験の度に多少の成績の動摇が免れ難 い.しかし通覧すれば Saccharomyces 群に対す ろ作用と Trychophyton 及び Penicillum 群に 対する作用は夫々異つて見える。. Saccharomyces 群に対してはてれら10盾の色素類は夫々作用濃度 を異にし，例えば $\mathrm{T}_{71}$ は $20 \mathrm{pmm}$ であり， $\mathrm{T}_{108}$ 及び T11日は $0.27 \mathrm{pmm}$ 程度である。

Trychophyton に対しても同様に各色素に差か あつて $\mathrm{T}_{71}, \mathrm{~T}_{72}, \mathrm{~T}_{100}$ 及び $\mathrm{T}_{101}$ 等が $11 \mathrm{pmm}$ 程度で作用し， $T_{112}, T_{116}$ 等が0.59〜0.83pmm 程度で作用する。乙の場合には Saccharomyces 群に見る程の作用浱度の上下の差が見られない。

Gibberella P Penicillium では全般的に作用が そしい.
結

論

Chinolin 又は Pyridine の halogen alkylate に Styrylの結合した10尰の感光色素の抗菌性に ついて実験の結果次の如き知見を得た。

1. Sacchalomyces に対しては $\mathrm{T}_{103}$ 及び $\mathrm{T}_{110}$ $0.27 \mathrm{pmm}$ が程度の有効性がある。

2. Trychophyton に対しては $\mathrm{T}_{112}$ 及び $\mathrm{T}_{14 \text { }}$ が pmml.0 以下で作用する。

3. Penicillium の発育に対しては注目すべき ものがない.

4. 牛乳の酸敗防止に関しては作用が充分でな い.

$$
\text { 文献 }
$$

本研究は厚生省科学研究䖭の援助によつた。記して深 く感諆します. 尚概要は“感光色素” No. 40P 22 24. (昭31) 飞載せた。 